\title{
G(n)o(s)tycyzm \\ Female queer gothic, gnoza i dyskurs o kobiecej potworności (o Almie Izabeli Filipiak)
}

\section{Potworność gatunku}

Alma Izabeli Filipiak to jeden z najdziwniejszych i najtrudniejszych tekstów najnowszej literatury polskiej, który - być może właśnie dlatego - został dość powszechnie zignorowany ${ }^{1}$. We wstępnych partiach nieokreślona bliżej narratorka konstruuje „list” powiadamiający o wejściu w posiadanie tajemniczego manuskryptu - zgodnie z kanonami najbardziej klasycznych powieści gotyckich - i jednocześnie sugeruje klasyfikację gatunkową: „To precyberpunk i neogotyk splecione razem"2. "Precyberpunk” uważam za określenie mylące - w samym „manuskrypcie” Almy brak wątków robotycznych, komputerowych, cybernetycznych, technologicznych, brak tu elementów dystopii czy utopii. Albo należałoby więc zawierzyć narratorce, że to „rodzaj wirtualnej gry”, i zastanowić się, czy narracja powieści przypomina narrację gry komputerowej (moim zdaniem - nie ${ }^{3}$; narracja jest hiperliteracka, kondensuje różne techniki, zdecydowanie czerpane z tradycji literackiej), albo uznać, że owa „cyberpunkowość” mieści się w ramie powieściowej, manuskrypt Almy miał bowiem powstać w latach 70. w ramach

* Instytut Badań Literackich PAN, Pracownia Poetyki Historycznej

1 "Monografizujący” rozdział w książce B. Warkockiego Homo niewiadomo. Polska proza wobec odmienności (Warszawa 2007) w ogóle nie wspomina o Almie. Badacz natomiast (s. 157-158) w kontekście lesbijskiego gotyku interpretuje inne opowiadanie Filipiak - Zdobycz $\mathrm{z}$ tomu Śmierć $i$ spirala.

2 I. Filipiak, Alma, Kraków 2003, s. 7.

3 Raczej to narracje gier komputerowych, gdzie chodzi się po lochach i korytarzach, przypominają klasyczny motyw gotycki niż odwrotnie. 
„projektu A", czyli PRL-owskich badań nad kosmicznymi turbulencjami i stanem nieważkości prowadzonych na kobietach; jednakże do tej "technologiczności" odnoszą się dwie strony w książce, sam zaś manuskrypt wcale. Moim zdaniem Alma przede wszystkim przetwarza konwencje klasycznej literatury gotyckiej, słabo obecnej w polskiej kulturze, problematyzując dodatkowo gotycką odmianę gender, co również nie jest w Polsce tematem przyswojonym, oraz wpisując się w gotycki subnurt „potworności", w polskiej kulturze obecny w jeszcze mniejszym stopniu; dodatkowo obecny w powieści dyskurs gnostycki zostaje w oryginalny sposób powiązany z gotycystycznymi kategoriami. Powieść Filipiak jest ponadto metaliteracka; wydaje się, że autorka przed jej napisaniem zapoznała się nie tylko z tekstami literackimi (sądzę, że Alma w dużym stopniu dialoguje z Frankensteinem Mary Shelley, mediowanym przez najnowsze XX-wieczne odczytania), ale także z nowszą refleksją teoretyczną nad nią nadbudowaną. Mogę się tylko domyślać, że znała książkę Judith Halberstam Skin Shows z 1995 r.

Niebywale skomplikowana fabuła i narracja Almy stawiają silną zaporę próbom uogólnienia jej "globalnego sensu”. Ktoś może powie, że to, co za moment zaproponuję, jest „unikiem”. Tak, byłby to unik z perspektywy tradycyjnej hermeneutyki czy hermeneutyki psychoanalitycznej. Moim zdaniem Alma, powieść napisana niezwykle precyzyjnie, tylko po części stwarza sugestię, iż posiada jakiś przekaz „pod powierzchnią", jakiś „głęboki sens", a jednak - programowo go nie posiada. Halberstam stwierdza, że gotycyzm jest „ekscesem” znaczenia i retoryki, który ukazuje ruinę znaczenia jako takiego, a czyni to za sprawą figury „potwora”:

[...] vertiginous excess of meaning. Gothic, in a way, refers to an ornamental excess [...], a rhetorical extravagance that produces, quite simply, too much. Within gothic novels, I argue, multiple interpretations are embedded in the text and part of the experience for horror comes from the realization that meaning itself runs riot. Gothic novels produce a symbol for this interpretive mayhem in the body of the monster. The monster always becomes a primary focus of interpretation and its monstrosity seems available for any number of meanings ${ }^{4}$.

Potwór jest wiązką znaczeń i interpretacji, nigdy niedającą się zredukować do jednego odczytania, może być rodzajem "ekranu projekcyjnego", na który czytelnicy projektują własne potrzeby czytelnicze (lęk i pożądanie przede wszystkim) ${ }^{5}$. "Potwór" jest centralną kategorią interpretacyjną w książce Halberstam - i główną bohaterką powieści Filipiak. Badaczka nie przypadkiem parokrotnie powtarza przestrogę Oscara Wilde'a, raz także

4 J. Halberstam, Skin Shows. Gothic Horror and the Technology of Monsters, Durham-London 1995, s. 2.

5 Por.: "The monster's body, indeed, is a machine that, in its Gothic mode, produces meaning and can represent any horrible trait that the reader feeds into the narrative. The monster functions as monster, in other words, when it is able to condense as many fear-producing traits as possible into one body. Hence the sense that Frankenstein's monster is bursting out of his skin - he is indeed filled to bursting point with flesh and meaning both" (tamże, s. 21). 
w charakterze motta: „ci, którzy schodzą pod powierzchnię, robią to na własne ryzyko". Izabela Filipiak każe bohaterkom - matce o wielu imionach i jej córce Almie - zejść "pod powierzchnię” ziemi, przez jamy do podziemnego świata „kobiecości”, aby odkryć „świat kobiecości i/jako okrucieństwa”, oraz pod zdzieraną skórę człowieka, aby odkryć „potwora”, pulsujące wnętrzności, ochłapy mięśni i krew. Alma ironizuje z idei poszukiwania esencji „kobiecości", jakiegoś das Ewig Weibliche. "Alma" wszak to anglosaskie imię żeńskie powstałe z łacińskiego "almus” („karmiący”, „łagodny”), a zarazem hiszpańska „dusza”, etymologicznie „anima” z łaciny. (O innych znaczeniach tego słowa dalej). Mamy tu więc po części kpinę z Junga, na którą nakłada się „poważny żart" z gnozy, ponieważ w powieści praktycznie nie występują żadni istotni bohaterowie męscy, nie licząc jakichś tancerzy w cyrku, stanowiących tło, czy rozszarpanego w tymże cyrku atlety. Jak zaś wiadomo, „anima” jest częścią psychiki męskiej, wewnętrznym archetypem kobiecości mężczyzny. Kto zatem jest mężczyzną? Czytelnik jako wyraziciel patriarchalnej kultury i patriarchalnego spojrzenia? A może „bóg”, który pojawia się w powieści w parodystycznej (ktoś powie: bluźnierczej) scenie ewidentnie jako mężczyzna, jako Wielki Fallus, który potrzebuje Almy, aby mieć syna: „(...) nie wywyższaj się [powiada jej], wybrałem ciebie nie ze względu na twoje nadzwyczajne zalety, jesteś młoda i zdrowa, a poza tym jesteś tak bardzo nikim, jak bardzo jest to możliwe" ${ }^{\prime \prime}$. Alma pieści z ironicznym zaangażowaniem Wielkiego Fallusa, który wytryska w niebiosa. To „bóg” z patriarchalnej bajki jest więc mężczyzną, mającym problem z „kobiecą” częścią swojej psychiki?

Inną hipotezę można by oprzeć na reinterpretacji Freudowskiej teorii sadyzmu dokonanej przez Gillesa Deleuze'a. Deleuze łączy w swojej analizie motyw powszechnej prostytucji obecny u de Sade'a oraz wyjaśnienie okrucieństwa, a także roli matki i ojca w doświadczeniu sadystycznym, które wyraźnie odróżnia od masochistycznego. Są to dokładnie te elementy, z których buduje swój świat Filipiak (burdel, kobiece okrucieństwo, matko - i córkobójstwo) - za wyjątkiem nieobecnej, lub raczej schowanej, pozycji „męskości”. Być może uda się wyjaśnić ten „brak” czy „ukrycie”, przeformułowując dyskurs Deleuze'a? Spójrzmy na ten cytat:
The dream of universal prostitution, as it appears in Sade's "society of the friends of crime", is embodied in an objective institution that aims to destroy the mother and give preferment to the daughter (the mother becomes an outcast and the daughter a partner) ${ }^{7}$.

A także: „The masochist's experience is grounded in an alliance between the son and the oral mother; the sadist's in the alliance of father and daughter"8. Filipiak podejmuje próbę wykreowania świata sadystycznego (w rozumieniu Deleuze'a, czyli takiego, gdzie sadysta napawa się zadawaniem cierpienia osobie, która sobie tego nie życzy; jest to raczej świat

6 I. Filipiak, dz. cyt., s. 47.

7 G. Deleuze, Coldness and Cruelty, [w]: Masochism. Gilles Deleuze "Coldness and Cruelty" and Leopold von Sacher Masoch "Venus in Furs", New York 1991, s. 62-63.

8 Tamże, s. 68. 
„okrucieństwa” niż „sadyzmu”, takiego jak ja go rozumiem, Filipiak też mówi o „okrucieństwie”, ale rozróżnienie Deleuzéa jest tu po prostu użyteczne), w którym matka ma być zniszczona na rzecz córki - ale bez pomocy czy inicjatywy ojca. Ponieważ Deleuze w swoim ujęciu zupełnie nie przywiązuje się do tradycyjnego kategoryzowania „męskie-żeńskie” i mówi np. o córkach zajmujących pozycję "syna" w masochizmie, to podążając za tym myślicielem, moglibyśmy właściwie uznać, że w świecie Almy „Ojciec" nie został usunięty, tylko wcielają go niektóre kobiety. Być może Filipiak przedstawia dwa konkurencyjne impulsy w kobiecie - zabić ojca i zabić matkę, przy czym obie te jakości czy pozycje są reprezentowane w powieściowym świecie przez postaci „kobiece”.

Z kolei idąc tropem „łagodności i karmienia” Almy, w miejscu „instynktu macierzyńskiego” i „,kobiecej łagodności” znajdujemy potworność. Główna bohaterka, matka Almy, jest złodziejką dzieci, które rozszarpuje i pożera. Sama o sobie powiada, że „kontynuuje badania nad zapoznaną sztuką okrucieństwa" ${ }^{\prime \prime}$. Ale nie jest wyjątkiem w tym niemal wyłącznie kobiecym świecie. Wszystkie żeńskie postaci zajmują się jakimiś formami okrucieństwa. Matka nie pożarła tylko jednego dziecka - Almy (kwestia „biologiczności” tego macierzyństwa jest zresztą skomplikowana, kiedy matka jest przesłuchiwana i torturowana w gabinecie Frygii przez inne kobiety, przedstawia kilka alternatywnych wersji swojej historii i nie wiadomo, w którą czytelnik ma „uwierzyć” - a raczej, czytelnik „ma nie wierzyć", bo nie ma w tym świecie „znaczeń pewnych”). Próbowała się go pozbyć, lecz ujęło ją okrucieństwo potworka, który wzoruje się zresztą na Matce:

próbowałam je porzucić już kilka razy, bezskutecznie, gdy zobaczyłam, jak żarłocznie rozrywa wciąż nie wystygłe, jeszcze drżące królicze ciałko, niew prawnie wyłuskuje trzepoczący miąższ, wypluwa strzępy sierści i co twardsze kosteczki. [...] to ona jest moją córką, ten nienasycony potwór ${ }^{10}$.

Wkrótce z równym zapałem kieruje się ku ciepłym zwłokom kobiet. O Almie wiadomo, że jest „włochatym monstrum” i że jej tożsamość córki, a więc kobiety, jest skutkiem procesu społecznego, nie tzw. biologii. Mianowicie, w scenie echem przywołującej Althusserowską „interpelację”, „obojnak", „hermafrodyta”, „potwór" został powołany na kobietę przez „matkę”: „Spostrzegłam, że dziecko posiada cechy płci tak męskiej, jak i żeńskiej. Teraz mówię: ona, tak postanowiłam: Jeśli jest potworem, niech będzie kobietą" $^{\prime \prime 1}$. To chiazm klasycznej tezy Arystotelesa z traktatu O rodzeniu się zwierząt: kobiecość jest „naturalną deformacją” męskości, innymi słowy, wyjściowy

9 Tamże, s. 69. Również gdy podróżując przez podziemny luksusowy burdel Frygii, będący jednocześnie rodzajem zakonu żeńskiego, trafia do miejsca, w którym domyśla się cyrku, stwierdza: „Czyżby Frygia znalazła w swym luksusowym burdelu miejsce dla sztuki cyrkowej, tak bliskiej zapoznanej sztuce okrucieństwa?" (tamże, s. 67).

10 Tamże, s. 17.

11 Tamże, s. 110. 
sylogizm Stagiryty brzmiał: ,„jeśli jest kobietą, to jest [niech będzie?!] potworem”"12. Oto „przesunięcie” Filipiak: skoro „potwór" w tradycji gotyckiego horroru jest tym, co może znaczyć "wszystko", to ironizując z esencjalistycznej wizji „kobiecości”, używa pisarka właśnie figury „potwora”.

A jednak wynika z powyższego pewna „nadwyżka”: wiedza o takim "amalgamacie" nie jest neutralna - przeraża i odpycha. Filipiak zresztą daje bardzo już ironiczny kontrapunkt. "Kobiecość” albo jest „wszystkim” (czyli jest „potworem”), albo jest „niczym” - i wtedy jest „perłą”. Pisarka włączyła w swój szyty z różnych skór dyskurs gnostycki Hymn o perle. Matka ma bowiem, jak gdyby w geście „sublimacji”, „wzniosłości” w miejsce „okrucieństwa", wizję (senną?) Almy - to jeszcze jedna alternatywna historia jej narodzin - jako istoty, która wyskoczyła z głowy matki do oceanu, gdzie rodzicielka znalazła "perłę”. Narracja ta zostaje przerwana, gdy niespodzianie w burdelu-klasztorze Frygii niejaka Andrea, przewodniczka naszej bohaterki, zaczyna opowiadać o sobie historię, która jest kontynuacją snu Matki o Almie. Tak więc Andrea wynurza się z oceanu z perłą w zaciśniętej dłoni, znajduje się na wyspie z dziewczętami, jest chora, lecz zdrowieje, gdy oddaje im perłę, jedna z nich zaś z czasem zwraca ją morzu. (Na koniec powieści przesłuchujące wmawiają Matce, że to Andrea jest jej córką. Ale czy to znaczy, że Almą? Oczywiście nie wiadomo. Podobnie jak nie jest pewne, że Andrea jest jej córką).

Czym jest owa krążąca między kobietami perła? - Otóż „niczym”. Jest ona purloined letter; zwróćmy uwagę, że w słynnym opowiadaniu Poego chodzi oczywiście o list (którego treści nikt nie zna, ale który - właśnie dlatego - ma moc trzymania wszystkich w szachu; może to pusta kartka?!), ale angielskie "letter" to też „litera”. Perła jest takim pustym desygnatem, miejscem na kabalistyczne "e-met” na tabliczce wkładanej w usta Golemowi (emet to "prawda”, po zmazaniu jednej litery met znaczy już „śmierć"). $\mathrm{W}$ dalszych partiach powrócę do wątku gnostyckiego. Jak zatem odpowiedzieć na głupie - jak sugeruje Filipiak, podążając wszak za tradycją feminizmu i queer - pytanie "czym jest kobieta/kobiecość"? „Wszystkim i/lub niczym", a więc potwornością lub "literą, której nikt nie widział”. "Jaki jest ostateczny sens powieści Alma?" - perła krąży.

A oto, jak potworność bohaterek zostaje metaliteracko przełożona na "potworność, czyli zarazem „hybrydyczność", „pasożytniczość” i „porażkę” tekstu. W podziemnym burdelu-zakonie kobiecym Matka w jednej z cel natrafia na twórczynie Wieloksięgu, virgines scriptionidicatae, siedzące przed ekranem i wzbudzające w sobie wizje, by następnie je zapisywać. Kontroluje je magistra docta electa, ale idea "kontroli” w świetle nazbyt tradycyjnie pojmowanych pojęć jest zupełnie sprzeczna z ideą Wieloksięgu, której strzeże: „Nie chcę narzucać wam kierunku [...], to zaprzeczałoby idei Wieloksięgu, w jego meandrycznych zakrętach i spiralnych załamaniach odbić"13. Nie ma on początku ani końca, ani jakiegoś określonego kształtu, choć

12 Por. A. Kowalcze-Pawlik, Obietnica potworności, [w:] Teorie wywrotowe, red. A. Gajewska, Poznań 2012, s. 495. Kobieta miałaby być początkiem kontinuum potworów, jej końcem - bezkształtne hybrydy.

13 Tamże, s. 60. 
„klienci” mogą sobie sprokurować indywidualne egzemplarze. („Klienci”, przypomnę, „burdelu przemienienia"). A jednak ruch między wizją a kontrolą w twórczości (także więc, rozumie się, w Almie) ma związek z potwornością, mianowicie:

Jest to funkcja [magistra docta electa - P. S.] przynależna tej z nas, która nie tylko najwięcej potworów potrafi wzbudzić w sobie, gdyż wzbudzone i nieokiełznane twory są tym, co najbardziej wytrąca nas z rytmu przywołanych obrazów, lecz która największą ich liczbę potrafi poskromić i zmusić, by nie one z niej, lecz ona z nich czerpała użytek ${ }^{14}$.

Oto pytanie o „poststrukturalność” świata, czyżby il n'y a horse texte w tym świecie? Może Matka nie zabija żadnych „zewnętrznych" potworów, tylko introjektowane „złe obiekty"?

W innym miejscu opis porodu Almy-potwora poprzedzają pytania: „Kto jest autorem tych wizji, przelatujących przez ekran jak zranione ptaki? Któż mógłby być ich twórcą, jak nie zatrzaśnięte we mnie dziecko?"15. Wydaje się, że w przypływie "kontrolowanej szczerości” pytania te zadaje w epifanii metaliterackości sama Izabela Filipiak, ale czy wypada być czytelnikiem tak naiwnym? Oczywiście, obraz zakonu „oddanych pisaniu" $i$ „,wybranej uczonej mistrzyni” przetwarza jakoś doświadczenie Filipiak jako prowadzącej zajęcia z „twórczego pisania dla młodych panien”; o takich zajęciach wspomina się też $w$ liście poprzedzającym manuskrypt. Chodzi więc także o écriture féminine, ale pomni przestróg Halberstam $\mathrm{o}$ „redukowaniu potworów” do jednej wiązki znaczeniowej nie redukujmy „potwora" do „zaszywania świata tekstem". Tekst to tkanina, to znana etymologia, ale w wypadku Almy, jak w wypadku gotyckich "potworów”, tkaniną tą są resztki skór. Tak przecież powstało dzieło Victora Frankensteina: z części ciał i kawałków skór różnych ludzi. Powieść Mary Shelley przedstawia fantazmat o męskim porodzie poza kobiecością. A jednak powieść jest napisana przez kobietę i - tu Shelley podąża za ideami politycznymi obojga swoich rodziców (Mary Wollstonecraft i Williama Godwina) - „prokobieca”. Shelley mianowicie przestrzega przed męską technokratyczno-scjentyficzną fantazją o tworzeniu ludzi bez udziału kobiet, ponieważ w kulturze patriarchalnej doprowadziłoby to do wymazania kobiet (i być może tym ta homoerotyczno-masturbacyjna fantazja o "dziecku" jest podszyta) ${ }^{16}$.

14 Tamże, s. 64.

15 Tamże, s. 93. Oto kolejny kamyczek na rzecz hipotezy, że Filipiak czytała Halberstam. Ta bowiem, omawiając kanibalizm gotycyzmu na przykładzie Frankensteina, formułuje analogiczne pytania: „The reading subject (but also the characters and seemingly the writer) of the Gothic is constructed out of kind of paranoia about boundaries: Do I read or am I written? Am I monster or monster maker? Am I monster hunter or the hunted? Am I human or other?" (J. Halberstam, Skin Shows, dz. cyt., s. 36). Wolę przyjąć założenie, że Filipiak czytała tę książkę, niż popaść w paranoiczny zachwyt, że oto udało mi się odnaleźć „ostateczne źródło wyjaśnienia" Almy, tak bardzo te książki przylegają do siebie.

16 J. Halberstam, Skin Shows, dz. cyt., s. 42, 45-47. Victor Frankenstein zabija ,kobiecego potwora", nim go ukończy, ponieważ przeraziła go wizja potworów rozmnażających się ze sobą i zaludniających świat kolejnymi potworami. Świat Almy jest poniekąd odpowiedzią na ten lęk: to świat pełen kobiet, a kobiety to wszak potwory, jeśli nie z definicji, to z interpelacji... 
Filipiak w scenie z bogiem wykpiwa ideę „męskiego rodzenia”, ale nie po to, by rewindykować kobiece, przeciwnie, albo uznamy, że Matka znalazła potworka i nie zjadła go, jak zjadła inne dzieci, tylko dlatego że wykazywał odpowiednią dozę uwodzicielskiego okrucieństwa, albo że biologicznie lub tekstowo - ją/go/je urodziła, lecz jako „eksces”, "defekt”. Monsterpiece w miejsce masterpiece, jak powiada w Skin Shows Halberstam. Jeśli tak określić zamierzenie Filipiak, to stworzyła ona masterpiece of monsterpiece. Ale to też nie przypadek, jak myślę, że w jednej ze swoich kolejnych książek Halberstam opisywała queer art of failure, to znaczy takie teksty, które wydają się "porażką", „nieudane” z perspektywy "normatywności” (np. smaku), „pomyłki artystyczne”, „niedoróbki”17. I tak właśnie przyjęto Almę. W podtekście Halberstam podsuwa jednak sugestię, że queerowe oko, patrzące $\mathrm{z}$ ukosa, potrafi dostrzec wartość czy siłę w takich domniemanych „porażkach", a te ukazują swoją siłę subwersywnego oporu. Jedna z badaczek powieści Shelley, Marie-Helene Huet, stwierdziła, że Frankenstein ustanawia „konieczne połączenie między potwornością a ogromną generatywnością" (może lepiej było zostawić to po angielsku, bo po polsku brzmi albo fatalnie, albo nieprzekładalnie: monstrosity and prodigious generativity) oraz że $\mathrm{w}$ romantyzmie dyskurs o potworach "tells of »the dark desire to reproduce without the other « and represents art as the resulting progeny of unnatural reproduction”18. Zwróćmy tylko mimochodem uwagę, że najbardziej „naturalną reprodukcją" w Almie byłaby ta z udziałem fallusa boga, a przecież i ona jest zupełnie "nienaturalna", poza tym nic nie wiadomo o tym, że Alma zaszła w ciążę. Co prawda boski fallus strzelił w niebiosa, więc nieco narcystycznie, ale anioł później Almę nawiedził, mówiąc jej, że urodzi syna (Alma spytała, czemu nie córkę), czy zatem - jakże „naturalne” - niepokalane poczęcie ma źródło w bezpłodności...?

\section{Gotycyzm kobiecy i męski, gotycyzm queerowy}

Alma włącza się ponadto w dyskusję nad "męskim” i „kobiecym gotycyzmem”, zainicjowaną jeszcze przez "krytykę towarzyszącą" pod koniec XVIII w., a podjętą w nowym języku feminizmu lat 70. XX w. Tradycyjnie przypisywano "męskiemu gotykowi" technikę "horroru”, a „kobiece$\mathrm{mu}^{\prime \prime}$ - „terroru"; mistrzem pierwszej był Matthew Gregory Lewis, drugiej

17 J. Esteban Muñoz w Cruising Utopia. The There and Then of Queer Futurity (New YorkLondon 2009, s. 173, rozdział zatytułowany After Jack. Queer Failure, Queer Virtuosity) sugeruje, że queerowe przerabianie, przetwarzanie porażki ma punkt wyjścia w uznaniu "homoseksualności" za "porażkę (w) heteroseksualności”. Oczywiście, dodałbym, tak też działa „kamp” - z normatywnego punktu widzenia, "porażka dobrego smaku” i "przetwarzanie kulturowych śmieci”. Badacz stwierdza dalej: "Queer failure is often deemed or understood as failure because it rejects normative ideas of value". Następnie uznaje, że „normatywność" i „normalność" mają tu wymiar antyutopijny i umyślne queerowe porażki mogą mieć charakter gestu utopijnego (także dlatego, że omijają ",heteroseksualny czas", straight time, a ten ma rytm reprodukcyjny). Zob. też J. Halberstam, The Queer Art of Failure, [w:] taż, The Queer Art of Failure, Durham-London 2011, zwł. s. 110.

18 M. H. H u e t, Monstrous Imagination, Cambridge-London 1993, s. 126. Cyt. za: J. Halberstam, Skin Shows dz. cyt., s. 29. Huet również przywołuje postać Golema jako jeden z archetypów potwora, wyraźny kontekst dla Frankensteina. 
- Ann Radcliffe. Ale już na przykład Charlotte Dacre i jej Zofloya wpisują się w "męski gotyk" (są też kontrprzykłady tekstów pisanych przez mężczyzn, a wpisujących się $\mathrm{w}$ „kobiecy gotyk" ${ }^{19}$. Analogiczny podział, tylko z użyciem innych kategorii, przypisywał "męskiemu gotykowi” dominację wzroku, wizualności, a także marzenia i fantazji (reverie), a "kobiecemu" estetykę wzniosłości, wiążącą się z, mówiąc nieco przesadnie, "zatkaniem” $\mathrm{w}$ zetknięciu z czymś przerastającym doznania zmysłowe, władzą. W efekcie "męski" podmiot miał opisywać bodźce związane z postrzeganiem kobiecego ciała, które zostawało uprzedmiotowione, „kobiecy” zaś zakładał masochistyczno-pasywną podmiotowość kobiety, dyscyplinowanej męską obecnością i spojrzeniem, przerażającym i przyjemnym równocześnie. Robert Miles, który rekonstruował archeologię tych wyobrażeń, dodał zresztą, że wiele tekstów hybrydyzowało i mieszało te pozycje ${ }^{20}$.

Donna Heiland stwierdziła, że konsekwencją tak pojmowanej „wzniosłości" jest wytworzenie akceptacji dla zabijania kobiet w fikcji literackiej i że sceny zabijania ich, w sprzężeniu, ową wzniosłość wytwarzają ${ }^{21}$. U Filipiak zabijanie nie wiąże się ze wzniosłością - pisarka unika w ten sposób pułapki patriarchalnego spojrzenia. Nie wiadomo, dlaczego kobiety zabijają, skąd okrucieństwo itd. Dacre jest pisarką niezwykłą i mogła być inspiracją także dla Filipiak, ponieważ przedstawiła kobiece podmioty jako aktywne, pożądające mężczyzny i wyraźnie reagujące na ich widok, a także okrutne, a nierzadko sadystyczne wobec innych kobiet, zwłaszcza gdy te stają im na drodze do zdobycia pożądanego mężczyzny (u Dacre kobieta najpierw pożąda, potem ewentualnie może się „zakochać”, ale zdarza się też, że zdobywszy mężczyznę, traci nim zainteresowanie). Okrucieństwo Victorii, głównej bohaterki Zofloyi, jest jednak dość „realistyczne” - oczywiście w kategoriach "realizmu gotycystycznego" - w porównaniu z Alma. U Filipiak zarówno Matka, jak i Alma przodują w okrucieństwie... W tradycji badań nad "kobiecym gotykiem" zarysowały się bowiem dwa konkurencyjne stanowiska: Ellen Moers, która bodaj pierwsza użyła terminu female gothic, wiązała go raczej z relacjami solidarności; Julian Fleenor natomiast zasugerowała, że jest to gatunek oparty na konflikcie z wszechwładną pożerającą matką ${ }^{22}$, Alison Milbank zaś dodawała, że female gothic ukazuje walkę córki, by odseparować się od matki w konflikcie preedypalnym ${ }^{23}$. Myśl Filipiak zdaje się powtarzać gesty tej drugiej linii. Być może - sugeruje ona - "kobieca potworność" jest wypartą kulturowo narracją, zasłoniętą przez

19 Por. K.I. Michasiw, Introduction, [w:] C. Dacre, Zofloya..., s. xiv-xv.

20 R. Miles, Gothic Writing 1750-1820. A Genealogy, Manchester 2002, s. 50-51, 57, 66, 81.

21 Por.: ,sublimity often - though not always - derives from scenes of fanstastic violence. Since that violence is very often directed against women, one can only conclude that these novels understand women as the embodiment of the "difference" that sublime experience eliminates. The aesthetically privileged category of the sublime experience then emerges as a way of rendering acceptable the deaths of women" (D. Heiland, dz. cyt., s. 14). Badaczka, podobnie jak Robert Miles, rekonstruuje znaczenie „wzniosłości” zgodne ze światopoglądem "gotycyzmu", tj. przede wszystkim na podstawie pism Edmunda Burke'a. Później pojęcie to redefiniowano.

22 J. Fleenor [wstęp do:] The Female Gothic, Montreal 1983, s. 16.

23 Podaję za D. Heiland, dz. cyt., s. 62. Badaczka uwzględnia także stanowisko Claire Kahane w tej dyskusji. 
dominującą (oczywiście patriarchalną) narrację (po)edypalną, gdzie kobiecość jest już „spacyfikowana”, masochistyczna. Choćby i dla tej przyczyny świat Almy jest światem bez Edypów, chyba że zachować zastrzeżenie płynące $z$ reinterpretacji Deleuze'a. Przede wszystkim jednak na tle tak zarysowanych opozycji gotycka propozycja Filipiak jest ewidentnie queerowa i, jak już widzieliśmy, polemizuje z preskrypcjami „kobiecości” jako „łagodności". Filipiak pisze więc "horror", nie „terror"; wyśmiewa estetykę wzniosłości i „zatkanie" męską władzą, pokazując cyniczno-ironiczną zabawę Almy Wielkim Fallusem boga; nade wszystko zaś eksponuje zmysł wzroku, co jest też zasadą dyskursu o „potworności”. Matka Almy używa wielu imion czasem także imienia Alma, aby nie było za prosto! - ale pierwszym wymienionym na przesłuchaniu u Frygii jest „DeMonstra”. Etymologicznie więc „ta, która pokazuje”24, ukazywanie jednak pochodzi od „potwora” właśnie. Pokazuje - komu? Jeśli jest w tym świecie jakiś męski podmiot, który akurat nie jest rozszarpywany (jak Atleta, którego mięśnie potem są zjadane), a z połowicznym prawdopodobieństwem można przyjąć, że wspominani klienci „burdelu przemienienia” są przynajmniej w części mężczyznami (tylko w ogóle o nich nie ma mowy), to jemu przypada w udziale masochistyczno-pasywna pozycja obserwatora horroru ${ }^{25}$. Podmiot ów wszak nie jest temu światu niezbędny.

\section{Gotycyzm i gnoza}

Aby zrozumieć miejsce dyskursu gnostyckiego w Almie, niezbędne jest sproblematyzowanie relacji gotycyzmu wobec gnozy, czego w systematyczny sposób w badaniach nad gotycyzmem nie przeprowadzono ${ }^{26}$. Nie chcę przez to powiedzieć, że Alma jest pierwszym tekstem gotycystycznym problematyzującym i hybrydycznie łączącym te dwa dyskursy, przeciwnie,

24 Alternatywna etymologia wywodzi też monstrum od moneo, „rada”, "ostrzeżenie” M. Warner, Chłopcy będa chłopcami: stwarzanie mężczyzny, przeł. A. Kowalcze-Pawlik, [w:] Teorie wywrotowe, dz. cyt., s. 559. O ile w wypadku „pokazywania” w Almie pytanie „komu?” jest zasadne, to w wypadku „ostrzegania” - nie (ofiarą może stać się każdy).

25 Burdel-klasztor ma architekturę Foucaultowskiego Panoptikonu. Kobiety niekiedy podglądają się przez wizjery.

${ }_{26}$ W teorii „filmu gnostyckiego" podkreślane są przez E. G. Wilsona aspekty gnostyckie, choć jednym z omawianych filmów jest Frankenstein Jamesa Whale'a (1931) czy - moim zdaniem bardziej gotyckie niż gnostyckie - Dziewiąte wrota Romana Polańskiego (1999) oraz A.I. Stevena Spielberga (2001). Pomimo że Wilson wprowadza podrozdział o gotycyzmie w filmie gnostyckim, nie proponuje precyzyjnej charakterystyki tych relacji. Ponadto problematyczne jest sprowadzenie przez autora gotycyzmu do jego postaci romantycznej i uznanie, że gotycyzm na ogół wiąże się z „ironią romantyczną” (która, oczywiście, jest pojęciem późniejszym niż pierwsze przedromantyczne powieści gotyckie). "Gnoza” zaś jest w tych rozważaniach bardzo niesprecyzowana (historycznie), sprowadzona do kilku idei-kluczy. Por.: „It is not surprising that the favored filmic genres of the ironic Kubrick and equally ironic Gnostic directors are gothic in flavor. Regardless of important differences, science fiction, film noir, horror, and fantasy all share key gothic elements: the blurring of realistic depictions of the familiar world and formalists experiments in outlandish dreams; the ambiguous melding of perception and projection; the conflict between reason and the unconscious" - E.G. Wilson, Secret Cinema. Gnostic Vision in Film, New York 2006. Cytuję autoryzowany przedruk w internetowym magazynie: http://voegelinview.com/gnosis-and-film-pt-4/ [dostęp z dnia 12 X 2015]. 
natomiast oryginalność tej powieści wynika z jej postmodernistycznej, feministycznej i queerowej reinterpretacji konwencji gotyckich $\mathrm{w}$ zestawieniu z przywołaniem zrębów dość tradycyjnego dyskursu gnostyckiego, który wszak z takiego zmieszania wychodzi zreinterpretowany. Poniższe uwagi, które przedstawię w syntetyzujących punktach, odnoszą się oczywiście także do innych niż Alma projektów literackich.

1. Dla uniknięcia nieporozumień przyjmuję ważne rozróżnienie terminologiczno-chronologiczne Jerzego Prokopiuka. Tak więc pojęcia "gnostycyzm” i "gnostycki” używane są w odniesieniu do "klasycznej” czy historycznej gnozy, to znaczy tej powstałej w starożytności. Fenomeny późniejszych „wiedz tajemnych” i ezoterycznych Prokopiuk proponuje określać mianem "gnozy" i przymiotnikiem "gnostyczny" - te dwa ostatnie mają znaczenie transhistoryczne ${ }^{27}$. Gnostycyzm powrócił w obszar kultury europejskiej jako przedmiot badań (oraz społeczna ciekawostka) dopiero z początkiem XIX wieku, a odkrycia kolejnych tekstów i ich rozumienie przyrastały przez kolejne dekady tego wieku i następnego. $Z$ tego powodu pierwsza faza gotycyzmu, XVIII-wieczna, nie pozostawała w żadnej relacji z gnostycyzmem, nawet w orientalnej fantazji Wathek Williama Beckforda. Jeżeli w swoich antychrześcijańskich akcentach zbliżała się jakkolwiek do gnostycyzmu, to należy mówić nie o świadomej inspiracji, a o zbieżnościach. Teksty tej pierwszej fazy oraz późniejsze pozostawały jednak niekiedy pod wpływem gnoz(y), szczególnie te powieści gotyckie, które dotyczyły czasów wypraw krzyżowych (np. Stary baron Clary Reeve) albo rozgrywały się na południu średniowiecznej i renesansowej Europy (Hiszpania, Włochy), co pozwalało autorom i autorkom wprowadzić (dość słabo na ogół znane sobie) wątki tradycji alchemii i ezoteryzmu. Dalsze dzieje konwencji gotyckiej pozostają już w synergicznym sprzężeniu z przyrastającą wiedzą na temat gnostycyzmu i późniejszych europejskich tradycji ezoterycznych. Można powiedzieć z pewną przesadą, że XIX-wieczne odkrycie Hellady znaczyło dla romantyków coś zupełnie odmiennego niż dla "gotów"28. Podobnie znaczące było „odkrycie” Egiptu. Gotycyzm późnodziewiętnastowieczny, „wiktoriański gotyk” w Anglii i Irlandii (zwłaszcza Skarabeusz Izydy Richarda Marsha), a także różne przejawy modernizmu europejskiego (Gustav Meyrink, Hanns Heinz Ewers, Edward Bulwer Lytton, w Polsce Stanisław Przybyszewski, Tadeusz Miciński, Antoni Lange) ze szczególnym zwróceniem uwagi na dekadentyzm (Là-bas Jorisa Karla Huysmansa) - to już gotycyzm bądź jego elementy fantazjujące i "pasożytujące” na gnozach i tradycjach ezoterycznych. Nawiasem mówiąc, dość nieoczywistą kwestią, jako że autor uchodzi za „pozytywistę”, jest obecność konwencji gotyckiej w takim właśnie rozumieniu w Faraonie Bolesława Prusa. Tu kwestia owej „synergii" może być badana wręcz jako relacje i wzajemne wpływy takich pisarzy i instytucji jak Towarzystwo Teozoficzne Heleny Bławatskiej czy Hermetyczny Zakon Złotego Brzasku (jak wiadomo, przez pewien czas był z nim

27 Zob. J. Prokopiuk, Triadyczna perspektywa relacji między dobrem a złem, [w:] Nieba i piekła. Okultyzm, mistyka i demonologia, Gdynia 2001, s. 183 (przypis 13).

28 Pojęcie M. Kilgour, The Artist as Goth, [w:] taż, The Rise of the Gothic Novel, LondonNew York 1995, s. 190, 215. 
związany William Butler Yeats). Bardzo często gotyckie przetworzenie takich gnoz, w tym historycznego gnostycyzmu, bywało powierzchowne, a także synkretyczne, jak też synkretyczny charakter miały doktryny Bławatskiej, Aleistera Crowleya czy Rudolfa Steinera. Teksty gotycystyczne sięgające po czyste postaci ezoterycznych doktryn albo reprezentują podgatunek gotyckich powieści historycznych, albo są nieliczne.

2. Pozostając na metapoziomie zbieżności - podobny status jak gnostycyzm wobec dominującego chrześcijaństwa i hellenizmu posiada gotycyzm wobec chrześcijaństwa i oświecenia. Hans Jonas opisuje ten status gnostycyzmu następująco: "głównie z własnego wyboru - jako agresor - pozostawał on od początku w stanie wojny"29. Konsekwencją tegoż jest gnostycki indywidualizm i nonkonformizm, odróżniający go wyraźnie od religii zinstytucjonalizowanych ${ }^{30}$. Te cechy nie są w każdej postaci gotycyzmu pierwszoplanowe - natomiast na ogół zarysowują się wyraźniej w podgatunku queer gothic w porównaniu z gotycyzmem niequeerowym. Obiektem ",agresji” gotycyzmu były nurty oświeceniowe fetyszyzujące racjonalizm i empiryzm, a także dogmatyka chrześcijańska, zarówno katolicka, jak i protestancka. Gotycyzm stanowić miał rodzaj memento, psychoanalitycznego Cienia wobec wszystkiego, co nazbyt uładzone i optymistyczne. Metaforę tę zapewne można (rezygnując z chronologii i hierarchii) odwrócić, mówiąc o („gotycystycznym") Cieniu, jakim gnoza była względem chrześcijaństwa, jakkolwiek należy mieć w pamięci, że gnoza - w przeciwieństwie do gotycyzmu - nie jest późniejsza od chrześcijaństwa (zwłaszcza w jego ostatecznie zinstytucjonalizowanych postaciach). Być może z powodu takiego właśnie stawania wobec określonych tradycji, w sporze, zarówno gnostycyzm, jak i gotycyzm są opisywane jako zjawiska zasadniczo synkretyczne ${ }^{31}$. Synkretyzm taki wraz z gnostycką ideą teokrazji (pomieszania bogów) - nasila się w gotycyzmie historycznie, zgodnie z moimi uwagami z punktu pierwszego.

3. Celem gotycyzmu było zwrócenie uwagi na fenomeny metafizyczne wymykające się zarówno poznaniu naukowemu, jak i doktrynalnej religii ${ }^{32}$, zatem nawet jeśli światopogląd ów krytykował formy religijności, to nie kwestionował metafizycznego doświadczania świata; w gnostyckiej krytyce religijności jako „zbyt powszechnej” (gdy wiedza dostępna jest tylko wybranym, zatem nie może przyjmować charakteru religii, tj. instytucji)

29 H. Jonas, Religia gnozy, przeł. M. Klimowicz, Kryspinów 1994, s. 12.

30 Tamże, s. 57.

31 Por. uwagi Jonasa: „Jednakże forma najważniejsza, w jakiej wschód w tym czasie partycypował w kulturze hellenistycznej, związana była nie z literaturą, lecz z kultem: religijny synkretyzm, który w późniejszej fazie miał się stać faktem najbardziej kluczowym, zaczynał przybierać realne kształty już w tym pierwszym okresie epoki hellenistycznej. Znaczenie pojęcia »synkretyzm« rozszerza się zwykle tak, by obejmowało również zjawiska niezwiązane z religią; w tym wypadku cała cywilizacja hellenistyczna może być nazwana synkretyczną, albowiem coraz bardziej stawała się kulturową mozaiką. W sensie ścisłym natomiast synkretyzm oznacza religijne zjawisko, które bardziej dokładnie oddaje starożytny termin »teokrazja«, tj. pomieszanie bogów. [...] Wzrastający prestiż wschodnich bogów i kultów w obrębie świata zachodniego był zwiastunem roli, jaką Wschód miał odegrać w drugim okresie, kiedy przywództwo przeszło w jego ręce. Była to rola o charakterze religijnym, podczas gdy grecki wkład do hellenistycznej całości miał postać kultury świeckiej" (tamże, s. 37-38).

32 Por. M. Kilgour, The Nature of the Gothic, [w:] taż, The Rise of the Gothic Novel, dz. cyt., s. 3. 
znajduje się podobne założenie. Zasadnicza różnica światopoglądowa, do czego jeszcze wrócę, wynika z tego, że w gotycyzmie "powrót wypartego", czyli "nagły atak metafizyki”, może się przydarzyć potencjalnie „każdemu” (choć są osoby predestynowane, ale w rozumieniu protestanckim - jak w Wyznaniach nawróconego grzesznika Jamesa Hogga - lub wydoskonalone w kontaktach z ukrytą stroną, np. Arab Zofloya w Zofloyi czy Matylda w Mnichu Matthew Gregory'ego Lewisa), gdy dla gnostyków oświecenie czy uzyskanie wiedzy jest na ogół efektem usilnych zabiegów przy świadomości, że efekty nie są dane „każdemu”33. Trudno jednak utożsamić gnostycką "wiedzę" jako „wszystko, co należy do boskiej dziedziny bytu, mianowicie porządek i historia światów wyższych, oraz to, co ma być jej efektem - mianowicie zbawienie człowieka" ${ }^{\prime 34}$, wedle formuły Jonasa, z gotycystycznym wychynięciem ducha czy pojawieniem się Szatana w celu pozyskania duszy ludzkiej dla piekła bądź dla krytyki roszczeń rozumu. Ostrożnie można by zasugerować, że postaci tekstów gotycystycznych znajdują się - z perspektywy gnostyckiej - gdzieś na początku drogi, w bardzo niskim świecie, i dostają dopiero sygnał z jakiejś wyższej warstwy kosmicznej. Przyjęcie perspektywy psychoanalitycznej w pojmowaniu gotycyzmu zupełnie uniemożliwia jednak taką analogię: „wyparte”, które powraca, jest czymś biegunowo odmiennym niż pneuma, którą człowiek nosi w sobie i która niekiedy może "drgnąć" jako wezwanie z wyższej warstwy kosmosu. Chciałbym jednak stwierdzić, że gotycyzm potrafi w różnych swoich przejawach oscylować między dwoma tak rozbieżnymi stanowiskami - a tym samym chcę powiedzieć, że jakkolwiek perspektywa psychoanalityczna jest niezwykle ważna $\mathrm{w}$ badaniu gotycyzmu, nie może uchodzić za wyczerpującą. Jeszcze jedna uwaga w kwestii gotycystycznej krytyki nauki - według Maggie Kilgour gotycyzm podkreśla narodziny nowożytnej nauki z alchemii i rozejście się tych dwóch ścieżek poznania, co wyraźnie wskazuje na subtekst gnozy (acz nie gnostycyzmu historycznego) w krytyce nauki ${ }^{35}$.

4. Z powyższym wiąże się odmienne postrzeganie kosmosu i związana $\mathrm{z}$ tym różnica $\mathrm{w}$ traktowaniu fabuły. Kosmos powieści gotyckich jest najczęściej kosmosem "tego świata”, podobnie jak w chrześcijaństwie, co $\mathrm{w}$ zestawieniu z kosmizmem gnostycyzmu oznacza swoisty "realizm”. Świat nadprzyrodzony w gotycyzmie jest tylko jeden, to znaczy jest jedną warstwą ponad "rzeczywistym”, podczas gdy w gnozie takich poziomów, które adept stopniowo przekracza, jest wiele. „To, co jest na dole, jest takie jak to, co jest na górze; a to, co jest na górze, jest takie jak to, co jest na dole" - przyjmując tę zasadę Hermesa Trismegistosa, trzeba zwrócić uwagę, że alegorie lub

33 Niektóre nurty gnostycyzmu podkreślają uzyskanie wiedzy poprzez wewnętrzną iluminację, inne podkreślają świętą i tajemną naukę, proces wtajemniczania. Niekiedy zresztą obie te ścieżki mogą się nakładać. Wiedza ta jest "nie z tego świata”, nie można jej uzyskać w sposób naturalny. H. Jonas, dz. cyt., s. 50-51.

34 Tamże, s. 50.

35 M. Kilgour, The Artist as Goth, dz. cyt., s. 196: „modern science detaches itself from alchemy, ridiculed as primitive superstition, in order to define itself. [...] modern science, superficially detached from its dark and murky past, becomes another version of it, just as the enlightened rational man, such as Godwin, liberated from the superstition that inhibited the thought of the past, recreates them in new monsters". 
alegoryczne fabuły, jakimi nierzadko są teksty gnostyckie (najdobitniejszym przykładem Hymn o perle), opisując coś, co daje się rozpoznać jako opowieść "Z tego świata" (skok do morza po perłę), dzieje się wewnątrz jednostki, ale ma aspekt zmagnifikowany, skosmizowany. Bohater gotycystyczny i jego historia nie odnoszą się do tak pojmowanego „na górze”, a uwewnętrznienie przeżywanych przygód (jako alegorie) zwykle jednak bliższe jest kategoriom psychoanalitycznym czy „introspekcji”, "podróży w głąb siebie”, "poznawania swojej jaźni" - bez odniesienia do idei kosmosu. Z punktu widzenia gnozy, twórcy i bohaterowie oraz cały świat powieści gotyckich podlegają zasadzie psychizmu, a nie pneumatyzmu; ale też całe chrześcijaństwo w świetle gnostycyzmu jest "psychiczne”, a nie "pneumatyczne”. Z powyższego wynika, że teksty gnostyckie dla gotycysty sprowadzane są na ogół do "tego świata”, czyli pewnej formy "realizmu” (dopuszczającego metafizykę). Teksty gotycystyczne zaś zdają się z perspektywy gnostyckiej przystawiać lustrzane odbicie, $\mathrm{w}$ obu tych konwencjach bowiem wyzyskiwane są często te same motywy, ale ze znamiennym odwróceniem ostatecznych kierunków i sensów. Jednym z gnostyckich motywów jest ",szata", oznaczająca "ciało" lub „świat” (wymiennie może być tu "namiot”). Idea ta ma odpowiednik w gotycystycznej filozofii „maski”, „zasłony”, „zakrycia”, także i "stroju”. Hans Jonas odnotował różnicę, o której mówię, omawiając fragment Hymnu o perle i dając przypis, że idea ta została odwrócona w Portrecie Doriana Graya, czyli powieści z okresu gotycyzmu wiktoriańskiego: „szata [w Hymnie o perle - P.S.] utożsamia się z tą postacią i działa niczym osoba. Symbolizuje ona niebiańską czy też wieczną jaźń osoby, jej ideę pierwotną, rodzaj alter ego, które przebywa bezpiecznie $w$ wyższym świecie, podczas gdy ona sama trudzi się na dole [...]. Wzrasta ona wraz $\mathrm{z}$ jego czynami i doskonali się poprzez jego trud" ${ }^{\prime \prime 3}$. Analogicznie $\mathrm{z}$ podstawowym gnostyckim obrazem i doznaniem świata jako więzienia czy lochów. W gnozie człowiek jest wrzucony w świat lochów („Wszechświat, domena Archontów, przypomina ogromne więzienie, którego najgłębszy loch stanowi Ziemia, widownia ludzkiego życia" ${ }^{37}$ - powiada Jonas), gdy to rozpoznaje, rozpoczyna się jego droga i wzywa go wyższy świat. W gotycyzmie świat także okazuje się lochem - lub okazuje się mieć ukrytą warstwę pod światem aktualnym o strukturze więzienia-lochów - ale to właśnie owe lochy wzywają. Zatem - raczej „wyparte” niż pneuma. Na ogół bezpieczne wyjście gotycystycznego bohatera z lochów do "tego świata”, kończące część powieści gotyckich (tych z „happy endem”), przynosi ulgę. To właśnie jest "psychizm” w rozumieniu gnostyka, pragnącego stać się "pneumatykiem”, podobnie jak kolejny element wspólny obu wielkim narracjom - idea "potwora". W największym skrócie, Frankensteina Mary Shelley można uznać za taką „obniżoną", „uczłowieczoną" w stosunku do gnostycyzmu opowieść o Demiurgu. Dla gnostyka zaś Victor Frankenstein, powołujący do życia hybrydycznego „nowego człowieka”, może być odczytany poprzez kategorię

36 H. Jonas, dz. cyt., s. 138.

37 Tamże, s. 58. I jeszcze może dobitniej: „(...) w myśli gnostyckiej świat zajmuje miejsce tradycyjnego świata podziemnego i sam jest już królestwem umarłych, to jest tych, którzy muszą zostać wskrzeszeni" (tamże, s. 83). 
"wielkiej alegorii" jako opowieść o złym Demiurgu, który stworzył "ten świat" ${ }^{\prime \prime}$. Jeszcze jedna uwaga rozróżniająca obie te narracje w kategoriach mitu - gotycyzm jest raczej dystopijny, domaga się ukazania "brzydkiej”, a skrywanej podszewki świata; gnostycyzm jest ostatecznie „utopijny”, bo jego wyraźnym celem jest zmusić człowieka do opuszczenia dystopii, jaką jest "ten świat" 39 .

5. Jeszcze jeden motyw wyraźnie zbliża do siebie gnostycyzm i gotycyzm - choć także i manieryzm, jakim go opisywałem ${ }^{40}$ - mianowicie motyw labiryntu. Nie podejmuję się w niniejszych szkicowych uwagach rozpatrzenia relacji manieryzmu do gnostycyzmu. Niewątpliwie manieryzm, jakim opisał go Gustav René Hocke, w swej historycznej postaci wiele czerpał z ówczesnej alchemii i wiedzy ezoterycznej (czyli gnoz) ${ }^{41}$, a zwrot manierystów późniejszych ku gnozom to także częsta zależność (znaczna część „ezoterycznego modernizmu", w tym dekadentyzm, wpisuje się w transhistorycznie pojmowany manieryzm). Manierysta jednak nie potrafi rozwiązać sprzeczności, która dla gnostyka nie stanowi problemu - manierysta pragnie mianowicie przebywać w labiryncie, ponieważ jego dzieło jest poprzez to skomplikowane, podobnie jak skomplikowany jest świat - a równocześnie ów manierysta, jakim opisuje go Hocke, pragnie wyjść z labiryntu ${ }^{42}$. Gnostyk znów zapewne powiedziałby, że manierysta jest psychikiem, który nie potrafi przekroczyć swej kondycji ku podążaniu ścieżką pneumatyków. Jeszcze inaczej wygląda sytuacja bohatera gotycystycznego, który, podobnie jak gnostyk, zostaje "wrzucony" w labirynt ${ }^{43}$, z tym że obowiązuje tu zastrzeżenie opisane $\mathrm{w}$ poprzednim punkcie, mianowicie gnostyk mówi o wrzuceniu $\mathrm{w}$ ",ten świat" $\mathrm{z}$ kosmosu, zaś bohater gotycystyczny zostaje raczej niespodzianie wyrzucony $\mathrm{z}$ "tego świata" na jakieś jego marginesy, ciemne lasy za miastem, w podziemne korytarze. Nie bez pewnej dozy racji ktoś obruszy się, że posługuję się dużymi uogólnieniami i abstrakcjami, prowadzę grę pojęciami czy kategoriami. Tak jest do pewnego stopnia, ale

38 Badaczka gotycyzmu Maggie Kilgour stwierdza zaś, że „Frankenstein is a central metaphor for the gothic genre as it thematises, and ultimately demonises, its own creation”. Innymi słowy artysta-got jest takim gnostyckim Demiurgiem (choć Kilgour nie zwraca uwagi na ten kontekst). Taż, The Artist as Goth..., s. 190.

39 Na temat utopii i dystopii (oraz atopii) w queer zob. przede wszystkim mój esej Towards Queer Subversive Atopia, "SQS. Journal of Queer Studies” 2015, nr 1-2, s. 1-14.

40 Zob. mój tekst Manieryzm, "poetyka" queer i subwersje mitów, „Teksty Drugie” 2013, nr 5, s. 77-105. O relacji kategorii „gotycyzm” i „manieryzm” (część literatury gotycystycznej jest manierystyczna, ale z pewnością nie całość) wspominałem w tekście definiującym queer gothic - zob. Queer gothic - queer modernism, "Poznańskie Studia Polonistyczne” 2014, nr 24, s. 71-93.

41 Por. G. R. Hocke, Świat jako labirynt. Maniera i mania w sztuce europejskiej w latach 15201650 i współcześnie, przeł. M. Szalsza, Gdańsk 2003.

42 Tu trzeba doprecyzować, że ów „labirynt” jest w tym wypadku najczęściej kategorią "psychopoetyki”, to znaczy kategorią stylu wynikającą z pewnej predyspozycji światopoglądowej. Chodzi więc o umyślne komplikacje i „dziwności” tekstu czy kreski, kompozycji. Dobrze obrazuje to idea samą nazwą sugerująca związki z ezoteryzmem, mianowicie malowanie i odbiór malarstwa jako dostrzeganie prospettiva segreta (sekretna perspektywa - pojęcie Athanasiusa Kirchera). s. $80-85$.

43 Por. o gotycystycznych labiryntach zob. F. Botting, Gothic, London-New York 1996, 
chodzi o zaprowadzenie porządku w szeregu kulturowych obrazów występujących $\mathrm{w}$ różnych kontekstach i tradycjach. Teraz przypomnę więc o swoim powiązaniu manieryzmu z dyskursem (w tym estetyką czy "poetyką") queer. Otóż chciałbym stwierdzić, że miejscem, gdzie rozmaite te aspekty alegoryczno-symbolicznie skondensowane $\mathrm{w}$ figurze labiryntu się przecinają, jest queer gothic.

6. Zawężając zaś nieco gotycyzm do jego wariantu queerowego, wskazać można następujące zbieżności z gnostycyzmem (mając też $\mathrm{w}$ pamięci wspomniany przeze mnie $\mathrm{w}$ punkcie drugim rebeliancki indywidualizm i nonkonformizm). Na poziomie meta gnostycyzm zmagał się z problemem doskonale znanym podmiotom queerowym, mianowicie $\mathrm{z}$ koniecznością wyrażania się w narzuconym i niewłasnym języku. Gnostycyzm zmuszony był wyrażać swoje idee i treści w grece, która nie miała odpowiedników, zaś to, co np. w syryjskim czy koptyjskim bardziej obrazowe, sprowadzała do "logosowych" pojęćt ${ }^{4}$. Z powyższego wynikły problemy, które językoznawcy opisują np. jako code switching, a które w teorii queer wyraża para pojęć cognoscenti - ignoranti (wtajemniczeni i niewiedzący), wyraźne echo idei gnostyckiej; mianowicie w reakcji na starcie z greką gnoza orientalna dokonała rozdziału na tradycję oficjalną i sekretną, ta pierwsza była wyrażalna $w$ grece, druga dotyczyła tego, co było nieasymilowalne hellenistycznie. Odniesienie powyższego do historycznego doświadczenia emancypacji kobiet czy gejów i lesbijek jest dość oczywiste ${ }^{45}$. Jeszcze jedna konsekwencja językowa to gnostycka teoria interpretacji pisma, która opiera się na mechanizmie stosowanym również w teorii queer jako resygnifikacja i przechwytywanie. Autorem pisma był bóg-stwórca, tu gnostycy zgadzali się z chrześcijanami, ale ów bóg-stwórca był oczywiście bogiem nieprawdziwym, demiurgiem, należy zatem odrzucić sens zamierzony jego wypowiedzi. Podobnie jednak jak teoria queer nie poprzestaje na akcie inwersji czy negacji, tylko zmierza ku subwersji, „ich niewypowiedzianym twierdzeniem było raczej to, że ów ukryty autor nieświadomie włączył do swej jednostronnej wersji wydarzeń jakąś prawdę, i że ta prawda może być wydobyta dzięki odwróceniu na opak zamierzonego przezeń znaczenia" ${ }^{\prime \prime 4}$. Oto więc (praźródłowa?) idea „czytania z ukosa”.

\section{Gnostycyzm Almy?}

Wspominałem wcześniej o możliwych znaczeniach tytułu - przede wszystkim o jego znaczeniu „dusza”. Jungowska anima nie jest co prawda tożsama ze znaczeniem "duszy" w gnostycyzmie, w tym drugim, przypomnę, zagubiona w labiryncie kosmicznym „dusza” jest niższa wobec "ducha”, ów - albo pneuma, w zależności od systemu - może być ukryty w duszy czy uwięziony $\mathrm{w}$ jej siedmiu szatach (stale powtarzająca się w tekstach gnostyckich

44 Por. H. Jonas, dz. cyt., s. 39-40.

45 Podobnie jak idea mimikry czy „pseudomorfizmu”, która znana jest nie tylko ludziom queer, ale też z dyskursu postkolonialnego, bo też oczywiście sytuacja gnostycyzmu w znacznym stopniu jest reakcją na kolonialny charakter Hellady. Por. H. Jonas, dz. cyt., s. 40.

46 Tamże, s. 109. 
liczba siedem odsyła do siedmiu znanych wówczas planet $\mathrm{w}$ rozumieniu astrologicznym) ${ }^{47}$. Jednak słowo „alma” może u Filipiak występować także $\mathrm{w}$ znaczeniu zaczerpniętym $\mathrm{z}$ pism gnostyckich, gdzie stanowi aramejski odpowiednik hebrajskiego „olam”. Słowo to ma wiele znaczeń - począwszy od "ten eon", co może oznaczać określoną jednostkę czasu kosmicznego, po "ten świat" (w obu wypadkach, oczywiście, jest to określenie pejoratywne z punktu widzenia gnostycyzmu), a ponieważ w pewnych nurtach owe "eony" upersonifikowano, oznacza ono także demoniczne istoty będące władcami "tego świata” w „tym czasie”. Mandejskie „almaya” (liczba mnoga od „alma”) może oznaczać „światy”, ale też „byty""8. Tytuł powieści Filipiak można uznać nie tylko za odniesienie do pojedynczego bytu, Almy (córki, a może i matki), ale też za ogólną kategorię „ten eon" czy „ten świat”. Inna rzecz, czy w ujęciu Filipiak opisującej świat bez postaci męskich bez mała, ma to być znaczenie zawężone $\mathrm{w}$ stosunku do rozumienia gnostyckiego, a więc "ten świat kobiet teraz". Z punktu widzenia gnostycyzmu redukcja taka byłaby prostacka; „świat współczesnego kobiecego continuum jako labirynt okrucieństwa", to brzmi dobrze może jako tytuł rozprawki feministycznej (choć trąci już zbanalizowaniem problemu badawczego), lecz jakże to nikłe $\mathrm{w}$ zestawieniu $\mathrm{z}$ siedmioma światami kosmosu? A jednak jeżeli przyjąć, że Filipiak ironizuje na temat idei „Wiecznej Kobiecości”, a tym samym zasad stałych, fundamentalnych ontologicznie, to należy uznać, że wątki gnostyckie są wplecione i zrekontekstualizowane niezgodnie $\mathrm{z}$ duchem gnostycyzmu, choć zgodnie z wyżej wskazanymi przeze mnie prawidłami relacji gnostycyzmu i gotycyzmu. Jednocześnie poddając zabiegowi ironii „wzniosłe” wątki kosmiczne, Filipiak nie zaprzecza całokształtem swojej wielowarstwowej (siedem sukni?) powieści jakiemuś możliwemu „wyżej”. Owo „wyższe” wręcz zupełnie zgodnie z gnostycką ideą przebłyskuje w tekście powieści jak pneuma w duszy. Także w rzuconych mimochodem, kapryśnie porównaniach. Na przykład: „A jeśli z cyrku wypędzeni czarodzieje błąkają się po gwiezdnych peryferiach, rozświetlając sobie drogę magicznym ogniem podebranym gwiazdom [... $]^{\prime \prime 49}$. Istotna jest tu oś horyzontalna: do cyrku narratorka "zstępuje na moment”. Jest to zatem ruch $\mathrm{w}$ dół ku podziemiu. Jednakże wygnanie $\mathrm{z}$ tego najwyraźniej utopijnego $\mathrm{w}$ jakiejś mierze miejsca powoduje, że czarodzieje błąkają się po kosmosie, czyli, jak można sądzić, warstwie wyższej. Filipiak daje do zrozumienia, że istnieje kilka „światów” (alm), ale niejasne są ich hierarchia i odniesienie do "tego świata" (cyrk nim jest? cyrk jest pod nim, acz duchowo istotniejszy?). Albo też opowieść narratorki o swoim życiu, które okazuje się przekraczać „wcielenia” (ma zatem reinkarnacyjny charakter, co jest wątkiem zapożyczonym przez gnostycyzm $\mathrm{z}$ religii indyjskich, $\mathrm{np}$. w syntezie gnostyckiej Maniego) i ma charakter przekraczania stanu uwięzienia, wyrażonego doskonale gnostyckim obrazem: „Tylko wtedy i przez chwilę mogłam poczuć się wyrwana z pułapki w kształcie ogromnego jaja wypełnionego

\footnotetext{
47 Tamże, s. 60.

48 Tamże, s. 68-69.

49 I. Filipiak, dz. cyt., s. 29.
} 
czasoprzestrzenną plazmą"50 ${ }^{\prime \prime}$ Wędrówka przekraczająca wcielenia przekracza także poziomy świata: „Kolejne pytania obrysowywały każdą następną czynność zbytecznymi szczegółami, jak zaplamiony stól, nocny powrót, kiedy potykałam się o spadające gwiazdy, ręka na łonie, krew na nożu $[\ldots]^{\prime \prime 51}$. Interesuje mnie oczywiście obraz gwiazd jako gnostycki. Nie tylko w aspekcie przekraczania heimarmene, rzekomej "harmonii gwiazd”, którą gnostycy kwestionowali, a dobitnie wyraził gnostyk Tadeusz Miciński w Ananke: "szydzę z rozpaczy gasnących gwiazd"52. Wyrażenie „spadające gwiazdy" opalizuje dwuznacznością. Potykać się można o gwiazdy już upadłe. Jak rozumiem, spadające znajdują się wciąż w locie, zatem Filipiak opisuje przestrzeń, w której mieszają się porządki na osi horyzontalnej, a może i warstwy - stół może fruwa, a może stoi na „ziemi", gwiazdy może znajdują się pod stopami lecącej po kosmosie narratorki (jeśli tak, może to i aluzja do lotu Małgorzaty u Bułhakowa). „Zmieszanie” jako kategoria opisująca powstanie i budowę tego świata to zresztą koncepcja powracająca w klasycznych gnostyckich tekstach, np. w Apokryfach Nowego Testamentu: „Kiedy woda żywa weszła w wodę mętną, lamentowała i płakała... Kiedy zmieszał wodę żywą z wodą mętną, ciemność weszła w światło" ${ }^{\prime 53}$. Ostatecznie jednak Filipiak bagatelizuje ów „kosmiczny” obraz jako „zbyteczne szczegóły". Zbyteczne tło czy sceneria, w jakiej narratorka dokonywała swoich zbrodni.

List Zofii Skorek do Autorki, wprowadzający w sam rzekomo odnaleziony tekst Almy, zawiera szereg aluzji do gnostycyzmu, podanych jednak w sposób „realistyczny”, a przeto możliwy do przeoczenia jako posiadający podwójne kodowanie. I tak dowiadujemy się, że autorka rękopisu Almy brała udział w sekretnym projekcie badawczym o kryptonimie „Azja” ${ }^{4}$. Nazwa jak nazwa, można rzec. Tajne projekty tajnych służb, można powiedzieć. Tak. Filipiak dokonuje wielkiego (i ironicznego) skrótu, w którym współczesne tzw. "teorie spiskowe" wydają się dalekim echem, a niekiedy bękartem myślenia gnostycznego (w znaczeniu szerszym), ezoterycznego. Popkulturowe narracje $\mathrm{o}$ „teoriach spiskowych" na ogół wszak nie potrafią się obyć bez jakiegoś sztafażu gnostycznego czy ezoterycznego, zaś same "sekretne stowarzyszenia” strukturalnie zorganizowane bywają jak historyczne organizacje gnostyczne (np. różokrzyżowcy) $)^{55}$. Tak jest $\mathrm{w}$ wypadku niezwykle popularnych powieści Dana Browna, z których pierwsza głośna, Anioły $i$ demony, ukazała się w Stanach Zjednoczonych w 2000 r., a najbardziej może znana, Kod Leonarda da

$\begin{array}{ll}50 & \text { Tamże, s. } 107 . \\ 51 & \text { Tamże, s. } 108 . \\ 52 & \text { T. Miciński, Wybór poezji, oprac. W. Gutowski, Kraków 1999, s. 105. Por. interpretację }\end{array}$ tego wiersza także w kontekście gnostycyzmu w mojej książce Tadeusza Micińskiego podróż do Hiszpanii, Torun 2005, s. 229-239.

53 Cyt. za: H. Jonas, dz. cyt., s. 73 (tam też komentarz) - o ile dobrze zrozumiałem system zapisu źródeł (bardzo niejasny) i faktycznie J216 odnosi się do rzeczonych Apokryfów Nowego Testamentu, a nie innych tekstów gnostyckich.

54 I. Filipiak, dz. cyt., s. 8.

55 Por. D.V. Barrett, A Brief History of Secret Societies, Philadephia-London 2007. Autor omawia m.in. Ku-Klux-Klan czy strukture mafii sycylijskiej oraz dyskurs na temat amerykańskich sekretów państwowych w prasie z odwołaniem do źródeł historycznych, z których pierwszymi chronologicznie są zoroastrianizm i gnostycyzm. 
Vinci - w tym samym roku co Alma. Choć, co dobrze pamiętam, w Polsce Dan Brown stał się pokupną gwiazdą dopiero w 2004 r., Filipiak mogła się zetknąć z jego twórczością podczas pobytu w Stanach lub dzięki swoim kontaktom to zresztą najmniej istotne. Powieści Browna można uznać za pop-gotycyzm w odmianie wyzyskującej pop-gnozę. Pisarce dużo bliżej w ironicznym podejściu do "teorii spiskowych" i jej gnostyckich źródeł do Umberta Eco jako autora Wahadła Foucaulta. Innymi słowy, "Azja” w liście Zofii Skorek odsyła jednak także do miejsca, gdzie narodziła się większość idei gnostyckich. Projekt ten dotyczył badań "kosmicznych", tu znów w rozumieniu nie gnostyckim (ale, jak twierdzę, do niego "sekretnie" odsyłającym), a dwudziestowiecznym: „prowadzono badania na ludzkich podmiotach dla stwierdzenia skutków długotrwałego poddania stanowi nieważkości oraz kosmicznych turbulencji. [...] Umieszczano ich $\mathrm{w}$ maszynach imitujących ruch statku kosmicznego i zawieszenie praw grawitacji i pozostawiano $w$ tych warunkach na wiele godzin"56. Jest to zatem sytuacja "zewnętrzna”, ,"kosmos zewnętrzny", ale stany psychiczne, $\mathrm{w}$ jakie popadły uczestniczki eksperymentu, dla niewtajemniczonych kwalifikujące się raczej do leczenia psychiatrycznego, niejako "obudziły" - pneumy? - narracje (czy „fabuły", bo o tych mowa w języku powieściowym) oscylujące pomiędzy opisanym już wyżej gotycystycznym dyskursem o potworności i gnostyckimi alegoriami o "kosmosie wewnętrznym" ${ }^{\prime 57}$. Poddawane eksperymentom kobiety były więźniarkami, co rzecz jasna także odsyła do podstawowego gnostyckiego obrazu świata jako więzienia i uwięzionej pneumy w duszy, a duszy w kosmosie.

U Filipiak występują aluzje do gnostyckiego Hymnu o perle. Jest to zresztą o tyle łatwe, że tekst ów ma charakter fabularny i alegoryczny, ale moim zdaniem nie jest to jedyna tradycja gnostycka, $\mathrm{z}$ której czerpie - równie istotna zdaje się gnoza walentyniańska, do której odsyłaczy eksplicytnych w tekście powieści nie ma. Po pierwsze, chciałbym przyjąć następującą hipotezę, która współgra z uwzględnieniem gnozy walentyniańskiej: wiemy z tekstu powieści, że narratorka znana jest pod wieloma imionami: DeMonstra, Selda, Lichwiarka, Zatrute Ziele, Święta Panienka co z Martwych Powstała, Donna na Zamku Beladonna, Lilit albo Pas Magiczny, Wywołaj Mnie a Może Przyjdę, Rączka Klarnecisty, Jutro Wieczór a Może Nigdy, Pustynia Miłości, Melania

56 I. Filipiak, dz. cyt., s. 9.

57 Por.: ,„jej opowieść to prawdziwy dziennik z podróży międzygwiezdnej, którą wykonała, o ironio, nie opuszczając wcale planety Ziemi" (tamże, s. 10). W gnozie indyjskiej (np. jodze i jej współczesnych przekształceniach) idea podróży kosmicznych poprzez kolejne "światy", odbywająca się w akcie medytacji, jest podobna do "gnostycyzmu zachodniego" (jakkolwiek azjatyckiego z pochodzenia). Por. np. S. Prabhupāda, Łatwa podróż na inne planety, [tłumacz nieznany], Warszawa 1991. O współczesnych ezoterycznych próbach wyjaśniania ufo (np. jako przejawiania się w aktualnym świecie "aeroform” z „czwartego stanu materii" - idea Trevora Constabla oparta na gnozie Rudolfa Steinera) pisał polski znawca gnozy Jerzy Prokopiuk, Ufo, czyli jawna tajemnica, [w:] C.G. Jung, Nowoczesny mit, przeł. J. Prokopiuk, Kraków 1982, s. 37-38. Sam Jung w swoim opisie ufo jako „nowoczesnego mitu” stwierdza, że podstawy fizyczne są najbardziej wątpliwe, koncentruje się natomiast na tym, jaki owe „widziane” rzeczy uruchamiają archetyp, jaki przywołują mit i czy można w tym wypadku mówić o zjawisku synchroniczności. Do podobnych interpretacji (psychologizujących, tj. sytuujących podróże po fizykalnym, „zewnętrznym” kosmosie jako podróże przez własną psychikę) odsyła Filipiak. 
spod Żabiej Nóżki, Mniszka Albo Pokutnica, Magna Lamia, Odszczekaj Coś Powiedział, Oka Bazyliszka, Jeszcze Wiele Innych, a także Alma ${ }^{58}$. Żart to nieco Rabelaisowski, a nieco barokowy, zaś pomny barokowej zasady, że nadmiar pokrywa pustkę, chcę zasugerować, że "prawdziwe" imię narratorki tu nie pada - a jest nim mianowicie „Sophia”. A zatem postać z różnych nurtów gnostyckich, ale nie z Hymnu o perle. Synkretyczny gest Filipiak, jak to interpretuje, podporządkowuje niejako Hymn o perle opowieści o Sophii znanej na przykład z gnozy walentyniańskiej. Sophia (będę teraz konsekwentnie używał tego imienia na określenie narratorki) mianowicie dostrzega rozdźwięk pomiędzy Almą „realną" a „wyśnioną”. Jakkolwiek nie jest pewne, że urodziła Almę, ponieważ być może ją porwała i nie zamordowała (jako dzieciobójczyni), Sophia uważa, że „realna” Alma jest potworem, to znaczy, że z niej narodził się potwór. Marzenie o Almie doskonałej zaś wprowadza wątki z Hymnu o perle: „,́́niłam sen o Almie, posążku z zagęszczonej wibracji światła, to ona jest moją córką, nie ten nienasycony potwór, którego urodziły skrzydła nietoperza i pewnej nocy Alma wyskoczyła z mojej głowy"59. Ta właśnie idealna Alma skacze ze skały do wody w poszukiwaniu perły. Oznacza ona pneumę. Bardziej interesuje mnie figura potwora, to w niej bowiem właśnie nakładają się dyskursy gnostycyzmu i gotycystyczny. Otóż Sophia jako matka potwora to obraz właśnie z gnozy walentyniańskiej. Sophia w niej to ostatni i najmłodszy z Eonów (przypomnę: aramejskie „alma” to m.in. „eon”), który popadł w "namiętność”, kierując się żądzą poznania „Ojca”, co jest niemożliwe i uświadamia zetknięcie $\mathrm{z}$ kresem. Wskutek tego Sophia zrodziła byt (przypomnę: aramejskie „alma” to m.in. „byt”) bezkształtny i niepoczęty. "Ten oderwany kompleks duchowych stanów jest teraz zhipostazowaną duchową substancją, nieposiadającą wszakże formy ani kształtu - jest niepoczętym "poronionym płodem «"60. Ów "poroniony płód" budzi w Sophii żal. Apokryf Jana przedstawia potworność płodu obrazowo: „ukazał się jej twór - niedoskonały i szpetny, albowiem uczyniła go w pojedynkę. A nie przypominał on swej Matki z racji odmiennej postaci... [mian. węża i lwa]... Odepchnęła go od siebie, by nikt z Nieśmiertelnych nie mógł go zobaczyć, albowiem zrodziła go będąc w stanie niewiedzy"61. Sophia u Filipiak łączy akt narodzin z próbą jakiejś „,aborcji wewnętrznej”, odsyłającej do Hymnu o perle i motywu „muszli” (skojarzenie muszla-macica i muszla-wagina to potoczna, nie tylko psychoanalityczna oczywistość):

I tak dziecko, właśnie dziecko, nieodwołalny dowód oddania ciała, które dla mnie, wierzyłam w to, było już hiperbolą i syntezą, padło ofiarą mej nienawiści, wynikającej z zagubienia i pomyłki. [...] A jednak dziecko było moje, wbrew oczekiwaniom ujawnione! Przekonana, że noszę w sobie

58 I. Filipiak, dz. cyt., s. 104-105.

59 Tamże, s. 17-18.

60 H. Jonas, dz. cyt., s. 198.

61 Cytuję za H. Jonasem, dz. cyt., s. 214. Apokryf Jana nie jest tekstem powstałym w obrębie gnozy walentyniańskiej, ale pokrewnej jej gnozy Barbelo. Por. też s. 321 podobny opis według rękopisów z Nag-Hammadi. 
potwora, zacisnęłam się jak muszla, by nigdy nie wydać na świat ohydnego monstrum, które ostatecznie ujawniłoby hańbę ludzkości ${ }^{62}$.

Teoretycznie - z punktu widzenia gnostycyzmu - obowiązują kategorie „męskie” i „żeńskie”, a to znaczy, że owa pomylona Sophia ma jakości żeńskie, a przedmiotem najwyższej acz niemożliwej wiedzy jest „Ojciec”, czyli jakość męska, są nieistotne, są alegoriami. Tu jednak feministycznie nastawionemu umysłowi, na przykład Izabeli Filipiak, przestaje być z gnostycyzmem po drodze. Nigdy, nawet w najbardziej uduchowionej spekulacji, nie jest bez znaczenia, które jakości mają status „męskich”, a które „żeńskich", gdyby zaś było to nieistotne, to w ogóle takiego przypisania by nie było - tak można by pokrótce zrekapitulować feministyczny ogląd sprawy. Dlatego właśnie Filipiak dokonuje swoistej obrony Sophii i jej potwornego dziecka, a także samej idei potworności - a czyni to, wykorzystując omówioną już wcześniej konwencję female queer gothic wraz z jej dyskursem o potworności. I mniejsza o to, że z punktu widzenia gnostycyzmu sytuuje to jej projekt (jej bohaterkę) w niższym miejscu na ścieżce poznania. To gnostycyzm jest $\mathrm{w}$ tej powieści wpisany niejako wewnątrz gotycyzmu, nie odwrotnie, choć, jak wskazywałem, autorka podsuwa pewne "prześwity” duchowości. Pozwalam sobie zaproponować, sam już nieco znużony tą paronomazją, neologizm "g(n)o(s)tycyzm”, gdzie nawet ikonicznie przedstawiona jest idea "zawierania się".

Owa feministyczna reinterpretacja gnostycyzmu obejmuje jednak także ideę „Ojca” czy „Boga”. Z tym że w tym wypadku nie musi to być reinterpretacja gnostycyzmu w poprzek jego idei - przede wszystkim z tego powodu, że nie wiadomo, jakiego (to znaczy którego) „Boga” Filipiak opisuje; najprawdopodobniej Demiurga, a wykazując jego ograniczenia, ponawia gest gnostycki. W opowieści ów Demiurg dla niepoznaki stale określany jest jako „Dobry Bóg". Wybiera Almę do zapłodnienia, ponieważ uważa ją za dziewicę, a on chce mieć syna. To nie jest czysta drwina z chrześcijaństwa. Jak wiemy, Alma czy Sophia jest jakością mimo wszystko (tj. mimo swojego błędu prokreacyjnego itd.) wyższego rzędu niż „dziewica” i także Demiurg63, a - z punktu widzenia gnostycyzmu to oczywiste - „Bóg”, który posiada pragnienia i daje je poznać innym bytom, nie jest „prawdziwym Bogiem”, musi więc być Demiurgiem. Innymi słowy, Filipiak ponawia gnostycki gest uznania chrześcijaństwa za niedostatecznie duchowe, niedostatecznie kosmiczne, koncentrujące się za bardzo na materii i sferze "psychizmu”. „Duchowe zapłodnienie” polega na tym, że Alma masturbuje fallus Dobrego Boga, który wytryskuje w niebo. Konsekwencje powyższego to już prawdziwie złośliwy żart z chrześcijańskiej idei niepokalanego poczęcia (żart jednak wciąż zgodny z duchem gnostycyzmu): do Almy przybywa Anioł, by jej zwiastować, że zaszła w ciążę niepokalanie. Tymczasem w jednej z wersji (,zwiastowanie” występuje tu bowiem

62 I. Filipiak, dz. cyt., s. 42-43.

63 Por. bardzo istotny cytat, ukazujący właściwą hierarchię i odsyłający do gnostyckiego obrazu kosmosu: „Rozbawiona tak nieziemską pomyłką zaśmiałam się po raz pierwszy od dnia jej [Almy - P.S.] narodzin, które przeklinałam kiedyś, a dobry Bóg w zdziwieniu patrzył, jak pod podmuchem śmiechu gaśnie gwiezdna maskarada" (tamże, s. 48). 
w trzech wersjach, być może aby podkreślić ideę „apokryfu”) Alma odkrywa, że "zwiastujący” jej Anioł - czyli mistyfikujący masturbacyjne zajście - sam jest w ciąży: „przypomniała sobie spęczniałe wargi niebios zamykające się nad plwociną [wytryskiem Boga - P.S.] i pojęła, co tak bardzo psuło harmonijne proporcje anielskiego ciała, nienaturalnie powiększony brzuch, jak wzdęty balon, podskakujący, kiedy tylko spadła nań jakaś zabłąkana iskra" ${ }^{\prime \prime 4}$. Upominając się o „kobiece”, Filipiak mówi - jak sądzę - że nawet jeśli tradycja chrześcijańska jest mizoginiczna (i homofobiczna) - co próbują reinterpretować nurty teologii feministycznej i teologii queer - to upomnienie takie jest dużo mniej heterodoksyjne w obrębie gnostycyzmu, choćby gnostycy nie chcieli na taką interpretację przystać. Ale gnoza to ścieżka jednostkowa, a w związku z tym zawsze ceniono $\mathrm{w}$ niej nonkonformizm i indywidualizm.

\section{B I B LIO GRA F I A}

D. V. Barrett, A Brief History of Secret Societies, Philadephia-London 2007.

F. Botting, Gothic, London-New York 1996.

G. Deleuze, Coldness and Cruelty, [w:] Masochism. Gilles Deleuze "Coldness and Cruelty" and Leopold von Sacher Masoch "Venus in Furs", New York 1991, s. 9-138.

I. Filipiak, Alma, Kraków 2003.

J. Fleenor, The Female Gothic, Montreal 1983.

J. Halberstam, Skin Shows. Gothic Horror and the Technology of Monsters, Durham-London 1995.

J. Halberstam, The Queer Art of Failure, Durham-London 2011.

D. Heiland, Gothic \& Gender. An Introduction, Malden 2004.

H. Jonas, Religia gnozy, przeł. M. Klimowicz, Kryspinów 1994.

C.G. Jung, Nowoczesny mit, przeł. J. Prokopiuk, Kraków 1982.

M. Kilgour, The Rise of the Gothic Novel, London-New York 1995.

J. Esteban Muñoz, Cruising Utopia. The There and Then of Queer Futurity, New York - London 2009.

J. Prokopiuk, Nieba i piekła. Okultyzm, mistyka i demonologia, Gdynia 2001.

B. Warkocki, Homo niewiadomo. Polska proza wobec odmienności, Warszawa 2007.

E.G. Wilson, Secret Cinema. Gnostic Vision in Film, New York 2006.

\section{STRESZCZENIE}

Artykuł proponuje interpretacje słabo opisanej powieści Izabeli Filipiak Alma (2003) w kontekście queer female gothic i dyskursu o „kobiecej potworności” zainicjowanego przez Frankensteina Mary Shelley. Autor dystansuje się wobec metatematycznej

64 Tamże, s. 55. 
uwagi genologicznej Filipiak, że jej powieść reprezentuje cyberpunk, wskazuje natomiast na liczne zbieżności z książką Skin shows Judith Halberstam. W drugiej części artykułu analizowane są odniesienia gnostyckie powieści Filipiak, trawestującej Hymn o perle w feministycznym ujęciu. Osobny akapit poświęcony został teoretycznemu ustaleniu ogólnych relacji między gotycyzmem a gnozą.

\section{Słowa kluczowe}

gotycyzm, queer gothic, kobieca potworność, gnoza, macierzyństwo

\section{S U M M A RY}

\section{Female queer gothic and feminine monstrosity discourse. Alma by Izabela Filipiak}

The article proposes an interpretations of Izabela Filipiak's little-known novel Alma (2003) in the context of queer female gothic and the "feminine monstrosity" discourse inspired by Mary Shelley's Frankenstein. The author disagrees with Filipiak's metathematic genological remark that the novel represents cyberpunk, while pointing to numerous points of convergence with the book Skin Shows by Judith Halberstam. The second part of the article analyses gnostic references in Filipiak's novel, which is a feminist rewriting of Hymn of the Pearl. A separate paragraph is devoted to theoretical determination of the general relationship between the gothic and gnosis.

\section{Keywords}

gothic, queer gothic, feminine monstrosity, gnosis, maternity 